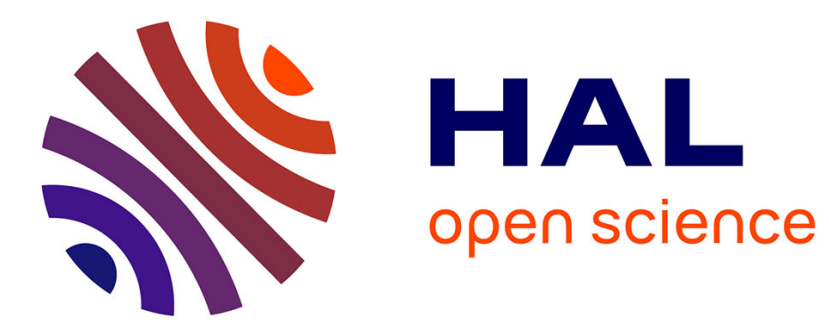

\title{
Enzymatic Assays for Probing Mitochondrial Apoptosis
}

\author{
Zhenyu Wang, Claire Nicolas, Rodolphe Fischmeister, Catherine Brenner
}

\section{To cite this version:}

Zhenyu Wang, Claire Nicolas, Rodolphe Fischmeister, Catherine Brenner. Enzymatic Assays for Probing Mitochondrial Apoptosis. Methods in Molecular Biology, pp.407-414, 2015, 10.1007/978-14939-2288-8_30. hal-02573449

\section{HAL Id: hal-02573449 \\ https://hal.science/hal-02573449}

Submitted on 14 May 2020

HAL is a multi-disciplinary open access archive for the deposit and dissemination of scientific research documents, whether they are published or not. The documents may come from teaching and research institutions in France or abroad, or from public or private research centers.
L'archive ouverte pluridisciplinaire HAL, est destinée au dépôt et à la diffusion de documents scientifiques de niveau recherche, publiés ou non, émanant des établissements d'enseignement et de recherche français ou étrangers, des laboratoires publics ou privés. 


\section{Enzymatic assays for probing mitochondrial apoptosis}

Zhenyu Wang $^{1,2}$, Claire Nicolas ${ }^{1,2}$, Rodolphe Fischmeister ${ }^{1,2}$ and Catherine Brenner ${ }^{1,2}$

${ }^{1}$ INSERM UMR-S 769, LabEx LERMIT, Châtenay-Malabry, France;

${ }^{2}$ Université de Paris-Sud, Faculté de Pharmacie, Châtenay-Malabry, France

Correspondence to:

Dr. Catherine Brenner, INSERM UMR-S 769, Université de

Paris-Sud, LabEx LERMIT, 5 rue Baptiste Clément,

Châtenay-Malabry, France;

E-mail: catherine.brenner-jan@u-psud.fr 


\section{Summary}

Isolated mitochondria are an invaluable analytical tool to probe mitochondrial function and evaluate apoptosis induction via the so-called mitochondrial pathway. Irrespective of their tissue origin (e.g. heart, liver, muscle, brain), these organelles participate actively to cell and life decision by producing energy for cell metabolism, but also by undergoing a lethal and irreversible mitochondrial membrane permeabilization (MMP) in stress and pathological conditions. MMP consequences consist, at least in part, in loss of mitochondrial transmembrane potential $(\Delta \Psi \mathrm{m})$, matrix swelling, arrest of respiration and ATP production, and cytochrome $c$ release from the intermembrane space to the cytosol. These parameters can be evaluated in vitro via several miniaturized assays, which have tremendous applications in the field of pharmacology, toxicology, diagnosis as well as drug discovery.

Key words: apoptosis, cytochrome $c$, fluorescence, heart, inner transmembrane potential, mitochondria. 


\section{Introduction}

During mitochondrial apoptosis, mitochondrial membrane permeabilization (MMP) has been previously defined as an irreversible process that leads to the cell death (1-3). Thus, MMP influences functional and morphological features of mitochondria depending on the nature, the intensity and the duration of the pro-apoptotic signal. Main stimuli of MMP are ions such as calcium $\left(\mathrm{Ca}^{2+}\right)$, reactive oxygen species (ROS) (e.g. anion superoxide, hydrogen peroxide), proteins (e.g. BAX, BID) and lipids and target the inner membrane, the outer membrane or both. Then, MMP results in loss of transmembrane potential $(\Delta \Psi \mathrm{m})$, matrix swelling, arrest of respiration and ATP production, ROS and cytochrome $c$ release from the intermembrane space to the cytosol (4-6). In some tissues such as the heart, abnormal mitochondrial fusion and fission can accompany mitochondrial apoptosis, but its contribution as cause $v s$ a consequence remains to be defined. Some of MMP parameters can be easily measured in vitro via several miniaturized assays to gain insights into pro-apoptotic mitochondrial alterations.

Here, we described the methods for (1) the isolation of fresh mitochondria from rat heart by a procedure adapted to the myofibrillar structure of the tissue, (2) the subsequent quantification of $\Delta \Psi \mathrm{m}$ by a fluorescent probe Rhodamine 123 (7) and the colloidosmotic matrix swelling by spectrophotometry (8), (3) the oxygen consumption by the phosphorescent probe Mito-ID ${ }^{\circledR}$ (9), and (4) the release of intermembrane space proteins, such as cytochrome c by western-blot (10). These assays are demonstrated to be useful analytical tools as well as high throughput screening tools implemented on technological platforms. Hence, they could have broad applications in the field of pharmacology, toxicology, and diagnosis as well as drug discovery.

\section{Materials}

All chemicals need to be of the highest purity available. All the reagents are from Sigma unless indicated otherwise. Ultrapure water is systematically used. 


\subsection{Isolation buffers}

$\begin{array}{lllll}\text { 1. Buffer } \mathrm{H} \text { : } & \text { weigh } & 102.8 \mathrm{~g} & \text { sucrose, } & 146 \mathrm{~g}\end{array}$ 2-[[1,3-dihydroxy-2-(hydroxymethyl )propan-2-yl]amino]ethanesulfonic acid (TES), 76mg ethylene glycol tetraacetic acid (EGTA). Add water to a volume of 900mL. Mix and adjust $\mathrm{pH}$ to 7.2 with potassium hydroxide $(\mathrm{KOH})$, add water to a volume of $1 \mathrm{~L}$. Mix and aliquot into $50 \mathrm{~mL}$ tubes and store at $-20^{\circ} \mathrm{C}$.

2. Buffer $\mathrm{H}+$ Bovine serum albumin (BSA): weigh 102.8g sucrose, $1.146 \mathrm{~g}$ TES, 76mg EGTA, 1g BSA. Add water to a volume of 950mL. Mix and adjust $\mathrm{pH}$ to 7.2 with $\mathrm{KOH}$. Complete to $1 \mathrm{~L}$ with water. Aliquot into $50 \mathrm{~mL}$ and store at $-20^{\circ} \mathrm{C}$.

\subsection{Mitochondria membrane potential and swelling}

1. Buffer S: weigh $68.46 \mathrm{~g}$ sucrose, $2.09 \mathrm{~g}$ 3-(N-morpholino)propanesulfonic acid (MOPS), 3.8mg EGTA, 82 $\mu \mathrm{L}$ Phosphoric acid (H3PO4). Add water to a volume of 950mL. Mix and adjust $\mathrm{pH}$ to 7.4 with $\mathrm{KOH}$. Complete to $1 \mathrm{~L}$ with water. Aliquot into $50 \mathrm{~mL}$ tubes and store at $-20^{\circ} \mathrm{C}$.

2. Succinate stock solution: weigh $1.35 \mathrm{~g}$ succinate; adjust the volume to $10 \mathrm{~mL}$ with water to get a concentration of $500 \mathrm{mM}$. Aliquot and store at $-20^{\circ} \mathrm{C}$.

3. Rotenone stock solution: dissolve $6.99 \mathrm{mg}$ of rotenone in $10 \mathrm{~mL}$ of absolute ethanol to a concentration of $2 \mathrm{mM}$. Aliquot and store at $-20^{\circ} \mathrm{C}$. (see Note 1)

4. Rhodamine 123 stock solution: weigh $3.81 \mathrm{mg}$ rhodamine 123 (Invitrogen), make up to $10 \mathrm{~mL}$ with absolute ethanol to get a concentration of $1 \mathrm{mM}$. Store at $-20^{\circ} \mathrm{C}$. (see Note 2)

\subsection{Oxygen consumption}

1. Measurement buffer: $250 \mathrm{mM}$ sucrose, $15 \mathrm{mM}$ Potassium chloride $(\mathrm{KCl}), 1 \mathrm{mM}$ EGTA, 5mM Magnesium chloride $(\mathrm{MgCl} 2)$, 30mM Potassium phosphate dibasic (K2HPO4), $\mathrm{pH} 7.4$

2. Reconstitute Mito-ID® Extracellular $\mathrm{O}_{2}$ Sensor kit (Enzo Life Sciences, Inc.) in $1 \mathrm{~mL}$ of nuclease-free water or media to obtain a $1 \mu \mathrm{M}$ stock solution. Mix gently. Aliquot into $100 \mu \mathrm{L}$ in tubes and store at $-20^{\circ} \mathrm{C}$. (see Note 3 ) 
3. Succinate stock solution: use the same as for membrane potential and swelling measurement.

4. Glutamate stock solution: weigh $0.94 \mathrm{~g}$ glutamate, add water to $10 \mathrm{~mL}$ to a concentration of $500 \mathrm{mM}$. Aliquot and store at $-20^{\circ} \mathrm{C}$.

5. Malate stock solution: weigh $0.45 \mathrm{~g}$ malate, add water to $10 \mathrm{~mL}$ to obtain a concentration of $500 \mathrm{mM}$. Aliquot and store at $-20^{\circ} \mathrm{C}$.

6. ADP stock solution: weigh $0.7 \mathrm{~g}$ ADP, make up to $10 \mathrm{~mL}$ with water to a concentration of $165 \mathrm{mM}$. Aliquot and store at $-20^{\circ} \mathrm{C}$.

\subsection{SDS Polyacrylamide Gel}

1. Loading buffer $(5 \times)$ : Tris $300 \mathrm{mM}$, Glycerol $50 \%$, sodium dodecylsulfate (SDS) 12.5\%, dithiothreitol (DTT) 50mM, BromoPhenol Blue 0.05\%, pH 6.8.

\section{2. $4-15 \%$ precast gel (BioRad Mini- PROTEAN TGX)}

3. Migration buffer (10×): weigh 30g Tris Base, 144g Glycine, 10g SDS. Add water to a volume of $950 \mathrm{~mL}$. Mix and adjust $\mathrm{pH}$ to 8.3 . Complete to $1 \mathrm{~L}$ with water.

4. DTT $(10 \times)$ : weigh $1.54 \mathrm{~g}$ DTT, make up to $10 \mathrm{~mL}$ with water. Aliquot and store at $-20^{\circ} \mathrm{C}$.

\section{5 Immunoblot}

1. Membrane (Trans-Blot Turbo Transfer Pack Bio-Rad)

2. Trans-blot Turbo transfer system (Bio-Rad)

3. Phosphate buffered saline (PBS)-Tween (10×): weigh 624mg Sodium dihydrogen phosphate monohydrate (NaH2PO4) 2.98g Na2HPO4 - Sodium phosphate dibasic (Na2HPO4), 204.5g Sodium chloride $(\mathrm{NaCl}), 12.5 \mathrm{~mL}$ Tween 20, make up to $2.5 \mathrm{~L}$ with water.

4. Antibody anti-cytochrome $c$ (BD Pharmingen)

5. Ultra-sensitive enhanced chemiluminescent (ECL) substrate, e.g. Supersignal West Femto Maximum Sensitivity Substrate (Thermo Scientific)

6. Gel imaging system, e.g. Chemidoc (BioRad) 


\section{Methods}

\subsection{Rat heart islated mitochondria}

1. Kill the rat after injection of pentobarbital and excise the heart rapidly and place it in cold buffer H. (see Note 4)

2. Rinse the heart free of blood by using ice-cold buffer $\mathrm{H}$.

3. Cut the heart into pieces in $10 \mathrm{~mL}$ of Buffer $\mathrm{H}$ with a scalpel blade and transfer them into a $50 \mathrm{~mL}$ falcon tube.

4. Grind the heart with the Polytron 2-3 times rapidly. (see Note 5)

5. Use the Potter to homogenize the mix.

6. Transfer the homogenate to a $15 \mathrm{~mL}$ Falcon tube and add $5 \mathrm{~mL}$ of Buffer $\mathrm{H}$ with BSA to fill the tube to $15 \mathrm{~mL}$.

7. Centrifuge at $500 \mathrm{~g}$ for $10 \mathrm{~min}$ at $4^{\circ} \mathrm{C}$. (see Note 6)

8. Collect the supernatant by eliminating the maximum of lipids and discard the pellet. (see Note 7) Centrifuge at 3,000 $\mathrm{g}$ for $10 \mathrm{~min}$ at $4^{\circ} \mathrm{C}, 2$ times (see Note 8).

9. Discard the supernatant and gently resuspend the pellet containing mitochondria in $200 \mu L$ Buffer H without BSA. (see Note 9)

10. Determine protein concentration in an aliquot by the BCA method following manufacturer's instruction using bovine serum albumin as standard. Keep the mitochondria on ice until use. (see Note 10)

\subsection{Mitochondrial transmembrane potential $(\Delta \Psi \mathrm{m})$ and swelling}

1. Prepare buffer $\mathrm{S}$ with final concentration of $5 \mathrm{mM}$ succinate and $2 \mu \mathrm{M}$ rotenone.

2. Prepare compounds (calcium as control of pro-apoptotic inducer or compound to be tested) in $4 \times$ concentrations with buffer $\mathrm{S}$. (see Note 11)

3. Add $50 \mu \mathrm{L}$ of compounds or buffer S (control) per well of microtiter plate 96 wells black with transparent and flat bottom.

4. Add $50 \mu \mathrm{L}$ of buffer S per well.

5. Dilute freshly isolated cardiac mitochondria at $0.25 \mu \mathrm{g} / \mu \mathrm{L}$ with buffer $\mathrm{S}$ and add rhodamine 123 to obtain a final concentration of $1 \mu \mathrm{M}$. Add $100 \mu \mathrm{L}$ of mitochondria in each well. (see Note 12) 
6. Shake the plate for $5 \mathrm{~s}$ and then start to measure for $60 \mathrm{~min}$ with 2 parameters at room temperature. For membrane potential, measure the fluorescence at $\lambda \mathrm{ex}=485 \mathrm{~nm}$ and $\lambda \mathrm{em}=535 \mathrm{~nm}$. For swelling, measure absorbance at $540 \mathrm{~nm}$.

\subsection{Oxygen consumption}

1. Warm up a microtiter plate 96 wells black flat bottom to $30^{\circ} \mathrm{C}$.

2. For compound testing, prepare compounds at $10 \times$ and add $20 \mu \mathrm{L}$ in the well. (see Note 8)

3. Dilute the respiratory substrate (glutamate/malate for complex I or succinate for complex II) with measurement buffer and add $20 \mu \mathrm{L}$ of this solution to obtain concentrations of $5 \mathrm{mM}$ (succinate) or 12.5/12.5 $\mathrm{mM}$ (glutamate/malate).

4. Dilute mitochondria suspension to $0.5 \mu \mathrm{g} / \mu \mathrm{L}$ with measurement buffer and add $100 \mu \mathrm{L}$ to each well. (see Note13)

5. Dilute ADP with measurement buffer and add $20 \mu \mathrm{L}$ to obtain a final concentration of $1.65 \mathrm{mM}$.

6. Add $30 \mu \mathrm{L}$ of measurement buffer to each well.

7. Add $10 \mu \mathrm{L}$ Mito-ID ${ }^{\circledR}$ Extracellular $\mathrm{O}_{2}$ Sensor probe in each well. (see Note 14)

8. Using a syringe dispenser, quickly add $100 \mu \mathrm{L}$ of oil to each well. (see Note 15)

9. Insert the plate into a fluorescence plate reader pre-warmed to $30^{\circ} \mathrm{C}$. Measure the probe signal for 30-60 min using excitation and emission wavelengths of $380 \mathrm{~nm}$ and $650 \mathrm{~nm}$ respectively. (see Note 16)

\subsection{Cytochrome $c$ release}

1. Use the same reaction system as membrane potential to increase the volume by 75 times. The final volume is $15 \mathrm{~mL}$ (see Note 12). Incubate mitochondria with the compounds or buffer (control) for 30min.

2. Centrifuge at $9,000 \mathrm{~g}$ for $15 \mathrm{~min}$ at $4^{\circ} \mathrm{C}$.

3. Collect supernatant in acetone-compatible tube.

4. Add four times the sample volume of cold acetone to the tube. (see Note 17)

5. Vortex the tube and incubate overnight at $-20^{\circ} \mathrm{C}$. 
6. Centrifuge at $15,000 \mathrm{~g}$ for $15 \mathrm{~min}$ at $4^{\circ} \mathrm{C}$.

7. Decant and properly collect of the supernatant. (see Note 18)

8. Allow the acetone to evaporate from the uncapped tube at room temperature for 30 $\min$.

9. Add $20 \mu \mathrm{L}$ of water and vortex thoroughly to dissolve protein pellet.

10. Take the same volume to measure cytochrome $c$ by SDS-PAGE and immunoblot.

\subsection{SDS-PAGE and western blot}

1. Add $14 \mu \mathrm{L}$ of cytochrome $c$ samples, $4 \mu \mathrm{L}$ of loading buffer $(5 \times), 2 \mu \mathrm{L}$ of DTT $(10 \times)$ into an eppendorf tube, mix and heat for $5 \mathrm{~min}$ at $95^{\circ} \mathrm{C}$.

2. Load the samples in the precast gel.

3. Migrate for $15 \mathrm{~min}$ at $300 \mathrm{~V}$.

4. Place the membrane and bottom stack on the cassette base, place the gel on top of membrane, roll the assembled sandwich to expel trapped air bubbles. Close and lock the cassette lid. Transfer for $3 \mathrm{~min}$ at $2.5 \mathrm{~V}$.

5. Block the membrane with 5\% of milk in PBS-Tween.

6. Incubate membrane with diluted anti-cytochrome c primary antibody in $5 \% \mathrm{w} / \mathrm{v}$ milk PBS-Tween at $4^{\circ} \mathrm{C}$ with gentle shaking, overnight.

7. Wash the membrane with PBS-Tween for $6 \times 5 \mathrm{~min}$.

8. Incubate the membrane with Horseradish Peroxidase-Conjugated secondary antibody for $1 \mathrm{~h}$ at room temperature.

9. Wash the membrane with PBS-Tween for $6 \times 5 \mathrm{~min}$.

10. Incubate the membrane with an ultra-sensitive enhanced chemiluminescent substrate for $5 \mathrm{~min}$.

11. Take images with a gel imaging system.

\subsection{Statistical analysis}

Data can be analyzed using Student's t-test and two-way ANOVA for comparisons of mean values to the different treatments tested. Results are presented as the mean \pm 
standard deviation (SD) of replicates experiments. Significance: *: $\mathrm{p}<0.05$, **: $\mathrm{p}<0.01$; $* * *: \mathrm{p}<0.001$. Significance is not shown in the figures for clarity reasons.

\section{Notes}

Note 1: Rotenone in organic solvents decomposes and is oxidized upon exposure to light and air. It is imperative to protect the stock solution from direct light by using an aluminium foil. Rotenone is highly toxic: avoid skin contact and inhalation.

Note 2: Rhodamine 123 is light sensitive, so keep it in aluminium foil and avoid exposure to light for long time.

Note 3: Protect the stock solution from direct light by using an aluminium foil. Avoid repeated freeze-thaw cycles.

Note 4: All the steps must be performed on ice.

Note 5: Pre-cool the glassware and homogenizer with pestle in an ice-bath $5 \mathrm{~min}$ before starting the procedure. Homogenization as well as the following steps must be carried out on ice to minimize the activation of proteases and phospholipases.

Note 6: Turn on the centrifuge and preset it $4{ }^{\circ} \mathrm{C}$.

Note 7: White layer on the top of the tube.

Note 8: Avoid the formation of bubbles during the resuspension process. At the last time, use buffer H without BSA.

Note 9: Do not dilute the mitochondria with buffer as mitochondria retain their

functionality for a longer time when kept concentrated, minimizing exposure to oxygen.

Note 10: Mitochondria are ready to be used in experiments; use the preparation within 1-3 $\mathrm{h}$ for better functional responses.

Note 11: If the compound is not soluble in water, it can be dissolved in DMSO or other solvent and then diluted with buffer S. It is better to use less concentration of organic solvent. And it is important to use the same concentration of organic solvent in the control well.

Note 12: In order to use less time, it is better to use multi-channel pipette to do this step. 
Note13: If the rate of oxygen consumption is too fast, we can dilute the mitochondria to $0.25 \mu \mathrm{g} / \mu \mathrm{L}$.

Note 14: shake the plate for $10 \mathrm{~s}$.

Note 15: Pre-warm mineral oil to $30^{\circ} \mathrm{C}$ on a water bath.

Note 16: Adjust the gain for an optimal reading of a positive control, and use the same parameters for a series of experiment.

Note 17: Pre-cold $\left(-20^{\circ} \mathrm{C}\right)$ acetone, a volume four times that of the protein samples to be precipitated.

Note 18: Be careful to not dislodge the protein pellet. 

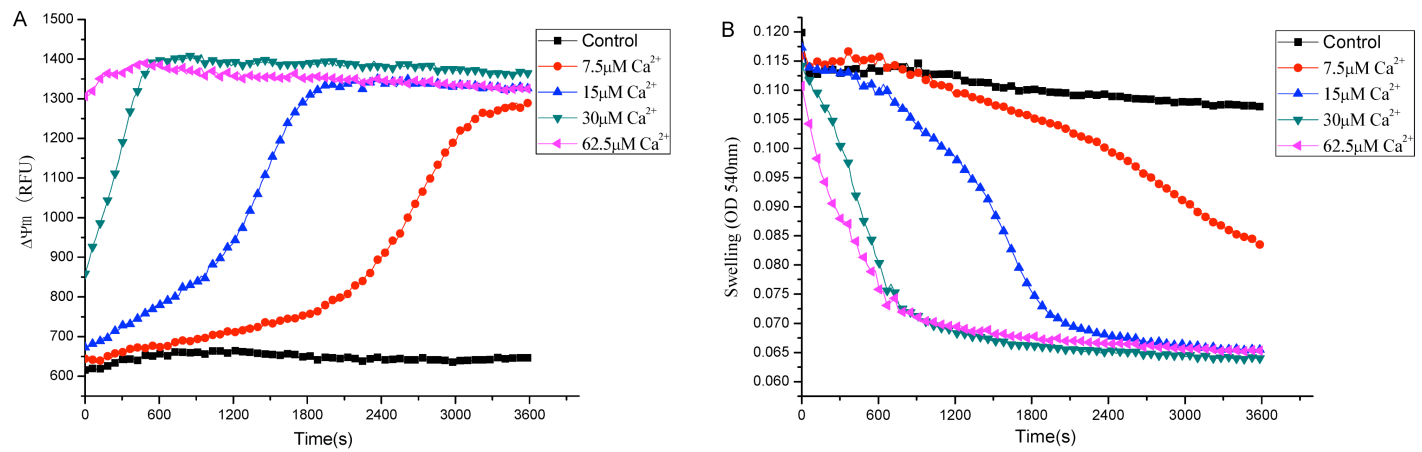

Fig.1. Co-evaluation of $\mathrm{Ca}^{2+}$ effect on the mitochondrial inner transmembrane membrane potential $(\Delta \Psi \mathrm{m})$ and matrix volume of cardiac mitochondria in microtiter plates. (A). Loss of $\Delta \Psi \mathrm{m}$ was simultaneously measured in real time following addition of increasing $\mathrm{Ca}^{2+}$ concentrations or without $\mathrm{Ca}^{2+}$ (Control) by fluorescence. (B). Mitochondrial swelling induced by different concentrations of $\mathrm{Ca}^{2+}$ was concomitantly monitored by absorbance.
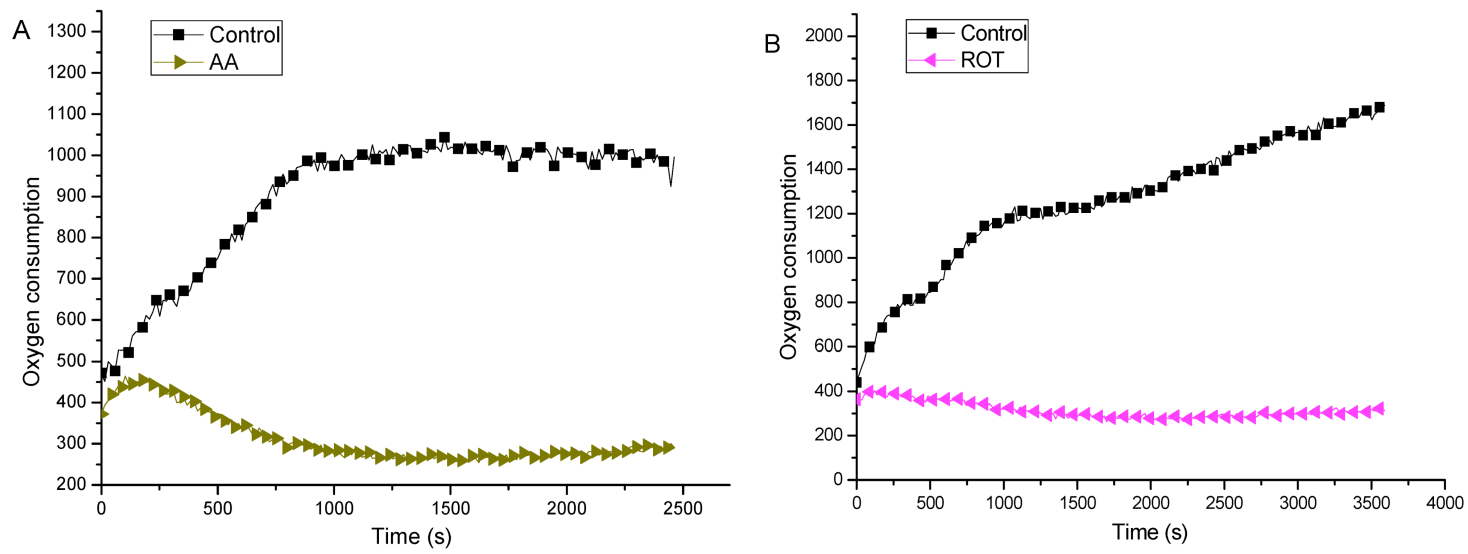

Fig.2. Assessment of ADP-stimulated mitochondrial respiration with Mito-ID ${ }^{\circledR}$ Extracellular $\mathrm{O}_{2}$ Sensor Kit. A: Oxygen consumption is driven by succinate (Control) and is inhibited by antimycin A (AA). B: Oxygen consumption is driven by glutamate/malate (Control) and treated with blocker rotenone (ROT). 


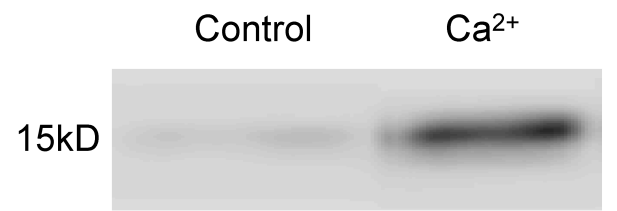

Fig.3 Immunoblot of cytochrome $c$ release from cardiac mitochondria treated with $10 \mu \mathrm{M} \mathrm{Ca}^{2+}$ or not (Control). The same volume of sample has been separated and electro-transferred according to (11) and immunorevealed using chemiluminescence. 


\section{Reference}

1. Martinou JC. Apoptosis - Key to the mitochondrial gate. Nature 1999;399:411-412.

2. Brenner C, Kroemer G. Apoptosis. Mitochondria--the death signal integrators. Science 2000;289:1150-1151.

3. Kroemer G, Galluzzi L, Brenner C. Mitochondrial membrane permeabilization in cell death. Physiol Rev 2007 87:99-163.

4. Zamzami N, Marchetti P, Castedo M, Decaudin D, Macho A, Hirsch T, Susin SA, et al. Sequential reduction of mitochondrial transmembrane potential and generation of reactive oxygen species in early programmed cell death. J. Exp. Med. 1995;182:367-377.

5. Gogvadze V, Robertson JD, Zhivotovsky B, Orrenius S. Cytochrome c release occurs via $\mathrm{Ca} 2+$-dependent and $\mathrm{Ca} 2+$-independent mechanisms that are regulated by Bax. J Biol Chem 1996;276:19066-19071.

6. Liu X, Kim CN, Yang J, Jemmerson R, Wang X. Induction of apoptic program in cell-free extracts: requirement for dATP and cytochrome C. Cell 1996;86:147-157.

7. Crompton M, McGuinness O, Nazareth W. The involvement of cyclosporin A binding proteins in regulating and uncoupling mitochondrial energy transduction. Biochim Biophys Acta 1992;1101:214-217.

8. Belzacq-Casagrande A, Martel C, Pertuiset C, Borgne-Sanchez A, Jacotot E, Brenner C. Pharmacological screening and enzymatic assays for apoptosis. Front Biosci. 2009;14:3550-3562.

9. Porceddu M, Buron N, Roussel C, Labbe G, Fromenty B, Borgne-Sanchez A. Prediction of Liver Injury Induced by Chemicals in Human with a Multiparametric Assay on Isolated Mouse Liver Mitochondria. Toxicol Sci 2012.

10. Martel C, Allouche M, Esposti DD, Fanelli E, Boursier C, Henry C, Chopineau J, et al. GSK3-mediated VDAC phosphorylation controls outer mitochondrial membrane permeability during lipid accumulation. Hepatology 2013.

11. Laemmli UK. Cleavage of structural proteins during the assembly of the head of bacteriophage T4. Nature 1970;227:680-685. 